\title{
Thrombocytopenia and absent radius (TAR) syndrome in pregnancy
}

\author{
Elisa Pereira, Ana Regalo, Lara Caseiro, Joaquim Carvalho
}

Hospital Espírito Santo, Évora, Portugal

\section{Correspondence to}

Dr Elisa Pereira,

elisa_pereira@hotmail.com

Accepted 12 September 2015

\section{DESCRIPTION}

A healthy 36-year-old Caucasian woman, P2002, a non-smoker who did not consume alcohol, with no history of exposure to teratogenic agents, presented, at a gestational age of 15 weeks, for prenatal care at our hospital. Ultrasound findings showed a live fetus with bilateral absence of the radius, with club hands, unilateral renal agenesis, a small stomach and cardiac anomalies. In this situation, with a high suspicion of fetal polymalformative syndrome, an amniocentesis was performed, with consent of the patient, at 16 weeks. The cytogenetic analysis demonstrated a normal male karyotype and the study for Fanconi anaemia was negative. It was not possible to carry out thrombocytopenia and absent radius (TAR) syndrome studies. A fetal echocardiogram was performed at 19 weeks and the diagnosis of type I truncus arteriosus was made, with non-restrictive ventricular septal defect. The patient and her husband, after counselling, opted for a medical interruption of pregnancy. This was performed at 24 weeks of gestation. A male abortus weighing $589 \mathrm{~g}$ was

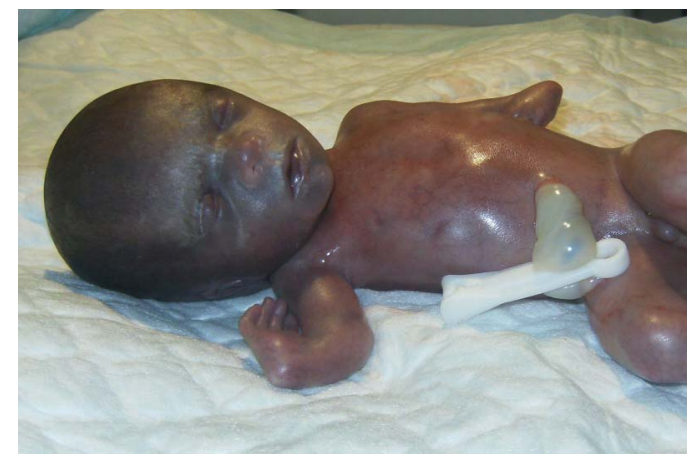

Figure 2 Male fetus after medical interruption of pregnancy.

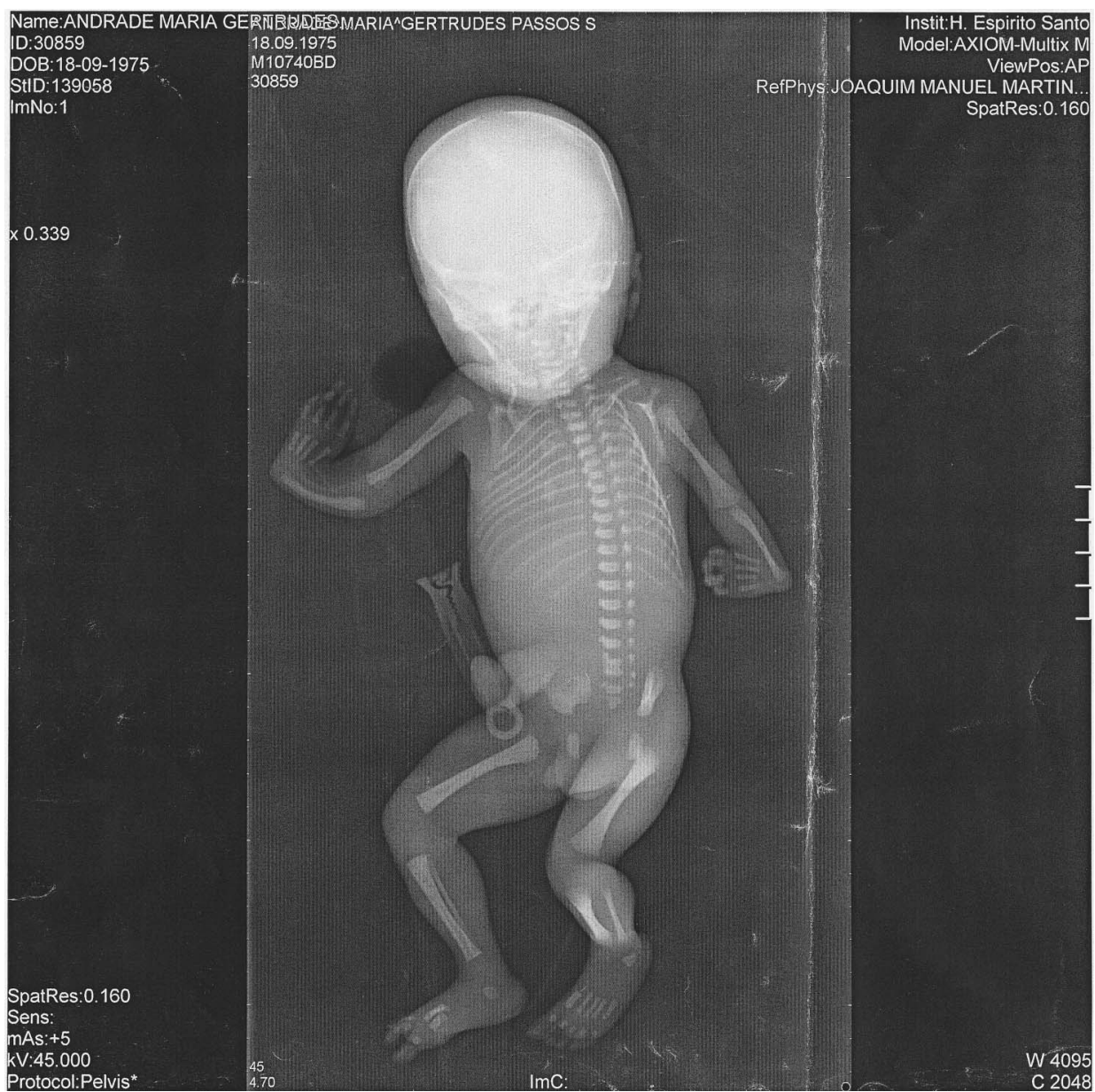

Figure 1 Radiograph of the fetus showing bilateral absence of the radius. 


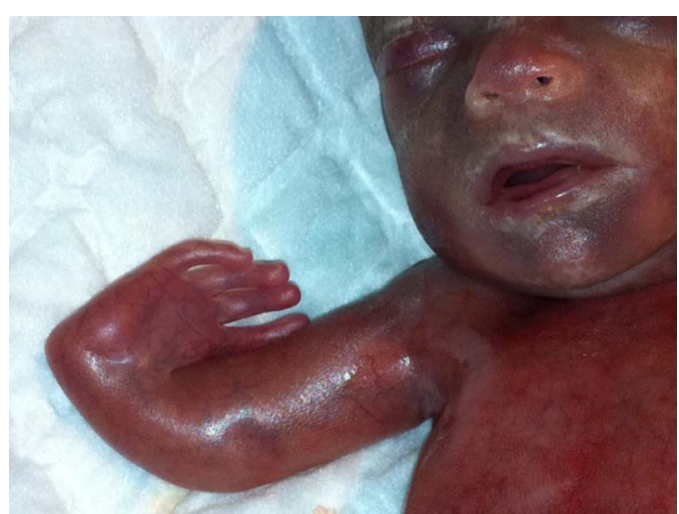

Figure 3 Macroscopic findings: club hands.

delivered. Postnatal findings confirmed a syndrome with malformations of the upper limbs, as seen on the subsequent radiograph (figure 1) and macroscopic findings (figures 2 and 3). Umbilical cord puncture was made for the evaluation of fetal platelet counts. Thrombocytopenia $(23000 / \mu \mathrm{L})$ was found in this case. The autopsy showed bilateral absence of the radius, with normal thumbs, oesophageal atresia, tracheo-oesophageal fistula, unilateral renal agenesis, one single umbilical artery and a congenital cardiovascular anomaly (truncus arteriosus), without congenital vertebral anomalies. Thrombocytopenia and autopsy findings confirmed the diagnosis of TAR syndrome.

\section{Learning points}

- Radial aplasia is associated with chromosomal, teratogenic and genetic causes. ${ }^{1}$ Thrombocytopenia is mandatory to differentiate thrombocytopenia and absent radius (TAR) syndrome from other malformations of the upper limbs.

- TAR syndrome is a rare disorder characterised by the absence of the radius; it is usually bilateral and presents a reduced platelet count. ${ }^{2}$

Competing interests None declared.

Patient consent Not obtained.

Provenance and peer review Not commissioned; externally peer reviewed.

\section{REFERENCES}

1 Boute 0, Depret-Mosser S, Vinatier D, et al. Prenatal diagnosis of thrombocytopenia-absent radius syndrome. Fetal Diagn Ther 1996;11:224-30.

2 Hall JG. Thrombocytopenia and absent radius (TAR) syndrome. J Med Genet 1987;24:79-83.

Copyright 2015 BMJ Publishing Group. All rights reserved. For permission to reuse any of this content visit http://group.bmj.com/group/rights-licensing/permissions.

BMJ Case Report Fellows may re-use this article for personal use and teaching without any further permission.

Become a Fellow of BMJ Case Reports today and you can:

- Submit as many cases as you like

- Enjoy fast sympathetic peer review and rapid publication of accepted articles

- Access all the published articles

- Re-use any of the published material for personal use and teaching without further permission

For information on Institutional Fellowships contact consortiasales@bmjgroup.com

Visit casereports.bmj.com for more articles like this and to become a Fellow 